\title{
DEBRIS FLOW HAZARD ASSESSMENT FOR THE OREGON CAVES NATIONAL MONUMENT
}

By John Friday

U.S. GEOLOGICAL SURVEY

Water Resources Investigations Report 83-4100

Prepared in cooperation with

NATIONAL PARK SERVICE

Portland, Oregon

1983 
CONTENTS

Page

Abstract---

Introduction-- 1

Basin properties-a- 2

Debris flow history-- 4

Hydrology-- 8

Debris flows-- 10

Soil sampling- 12

Site properties-D-n 12

Site A-1- 12

Site B-1

Site B-2- 13

Site C-1-1 13

Site $\mathrm{D}-1-\ldots$

Site $\mathrm{E}-1$

Site F-1-_- 14

Soil analysis-ar 14

Failure potential-aro 16

Hazard abatement--_- 18

Conclusions--- 18

Selected references-_- 19 


\section{UNITED STATES DEPARTMENT OF THE INTERIOR}

JAMES G. WATT, SECRETARY

GEOLOGICAL SURVEY

DALLAS L. PECK, DIRECTOR

For additional information write to:

U.S. Geological Survey, WRD

$8 \overline{47}$ N.E. 19th Ave., Suite 300

Portland, Oregon 97232
Copies of this report can be purchased from:

Open-File Services Section Western Distribution Branch U.S. Geological Survey

Box 25425, Federal Center Lakewood, Colorado 80225

(Telephone: (303) 234-5888) 


\section{ILLUSTRATIONS}

Page

Figure 1. Map showing tourist facilities and location of Oregon Caves National Monument--------_--------- 3

2. Photograph of debris-flow scar on No Name Creek-- 5

3,4. Photographs of mud I ines inside chateau---_-- 6

5. Photograph of damage and debris deposits at the facilities----- 7

6. Photograph of damage and debris deposits at the facilities-c- 8

7. Map showing location of sampling sites--_---_--_--- 9

8. Flood-frequency relation for Cave Creek at the chalet--_- 10

\section{TABLES}

Table 1. Summary of Atterburg limits test---- 15

2. Summary of particle-size analyses---16-- 16 
[For the use of those readers who might prefer to use metric
rather than inch-pound units] MULTIPLY

BY

TO OBTAIN

Inch (in.)

Foot $(f+)$

25.4
0.3048
1.609

0.3048

1.609

2.59

Square mile $\left(m i^{2}\right)$

0.0283

Cubic foot per second $\left(f t^{3} / s\right)$

0.7646

Millimeter ( $\mathrm{mm}$ )

Meter ( $m$ )

Kilometer $(\mathrm{km})$

Square kilometer $\left(\mathrm{km}^{2}\right)$

Cubic yard $\left(y d^{3}\right)$

Cubic meter per second $\left(\mathrm{m}^{3} / \mathrm{s}\right)$

Cubic meter $\left(\mathrm{m}^{3}\right)$

Temperature in degrees Fahrenheit $\left({ }^{\circ} \mathrm{F}\right)$ can be converted to degrees Celsius $\left({ }^{\circ} \mathrm{C}\right)$ as follows:

$$
{ }^{\circ} \mathrm{F}=1.8^{\circ} \mathrm{C}+32
$$

\section{NOTE}

National Geodetic Vertical Datum of 1929 (NGVD of 1929): A geodefic datum derived from a general adjustment of the first-order level nets of both the United States and Canada, formerly called mean sea level. 


\title{
DEBRIS FLOW HAZARD ASSESSMENT FOR THE OREGON CAVES NATIONAL MONUMENT
}

By John Friday

\begin{abstract}
Having experienced a devastating debris flow in the Oregon Caves National Monument, the National Park Service needed an evaluation of the potential hazard from additional flows. Soil properties at six randomly chosen sites were compared with those at the source of the debris flow. Although all sites had soils that could become unstable with sufficient moisture, soils at one site had properties similar to those at the scar and a potential hazard was identified.
\end{abstract}

The report suggests that winter weather conditions be closely monitored and compared with the antecedent weather that caused the known failure. When the threshold for additional mass wasting is believed imminent, appropriate action could be taken to insure the safety of park personnel and the public.

The peak streamflow that preceded the flow of 5,200 cubic yards of debris is estimated to have a 0.5 percent chance of being equalled or exceeded in any given year.

\section{INTRODUCTION}

Of the various hydrologic hazards in our environment, the mass movement of earth material caused by excess moisture can be one of the most destructive. These events often go unnoticed because they occur in unpopulated mountainous terrain during winter seasons. This was not the case in December 1964, when a major debris flow occurred in the Cave Creek drainage of the Oregon Caves National Monument.

In March 1982, the National Park Service (NPS) requested a study be made to appraise the possibility of a recurrence of the 1964 debris flow in the interest of safegarding the public and employees of the National Park Service. Public tours of the caves are conducted daily, and tourists are housed in various facilities during the summer season. The concession staff and park employees are year-around residents.

To appraise the hazard, soil properties at the source of the 1964 debris flow were compared with those from six other random locations within the Cave Creek basin. The physical characteristics of the overburden were determined from augered holes at each site. The size distribution of material obtained at various depths was determined by sieve analysis and the plasticity of each sample was determined by Atterburg limits. A small-diameter polyvinyl chloride (PVC) casing was inserted in some of the augered holes to accommodate a soil-moisture sensing device if a remote sensing early-warning system is deemed appropriate. 
Included in this study is an estimate of the amount of debris material that was deposited at the facilities in 1964. Also included is an estimate of the stream's discharge just prior to the arrival of the debris.

The author gratefully acknowledges the assistance given by Park Service personnel and by the management team of the Oregon Caves Company. A special thanks is given to Harry Christensen for his eye-witness account of the debris flow, and also to Tim Seemen, soil scientist (Corps of Engineers), for his suggestions and guidance during the interpretative phase of this study.

\section{BASIN PROPERTIES}

The Oregon Caves National Monument is in the Siskiyou Mountains in southwestern Oregon, 6 miles north of California and 46 miles inland from the Pacific Ocean ( $f i g .1)$. This pristine area is protected as a Wildlife Refuge and as a National Monument. The Monument has a total area of $0.70 \mathrm{mi}^{2}$; the Cave Creek drainage upstream from the tourist facilities is $0.32 \mathrm{mi}^{2}$.

Timber growth on the steep mountain slopes consists of virgin stands of Douglas fir, cedar, Shasta red fir, and white fir. The understory includes tan oak, canyon live oak, madrone, alder, rhododendron, and small white fir. The ground cover consists of false hellebore, bear grass, Oregon grape, and deerfoot vanilla leaf. The soils that allow such lush growth are in the Jayar and Althouse series and are a very gravelly silt and loam (U.S. Soil and Conservation Service, 1982).

Soils that form the overburden overlie metamorphosed volcanic and interbedded sedimentary rocks, and granitic intrusive rocks (state of Oregon, 1979). The Caves were formed by water dissolving the calcium carbonate in a marble pod that is totally encompassed by metavolcanic rock. An exposed bedrock interface in a cutbank area near the maintenance yard is highly weathered limestone. Limestone outcrops are also evident along the southern boundary of the basin where elevations exceed 5,200 feet. The elevation near the Cave entrance is 4,100 feet; the basin slope ranges from $20^{\circ}$ at the chalet to $45^{\circ}$ at the talus slope near the rimrock divide.

The Cave Creek basin faces west and has direct exposure to Pacific storm fronts that usually have prevailing westerly winds. The average annual temperature at the nearest weather station in Cave Junction, 13 miles west of the Caves, is $54^{\circ} \mathrm{F}$. The mean annual precipitation at the Caves is about 60 inches, much of which falls as snow from November to March (U.S. Weather Bureau, 1964). 


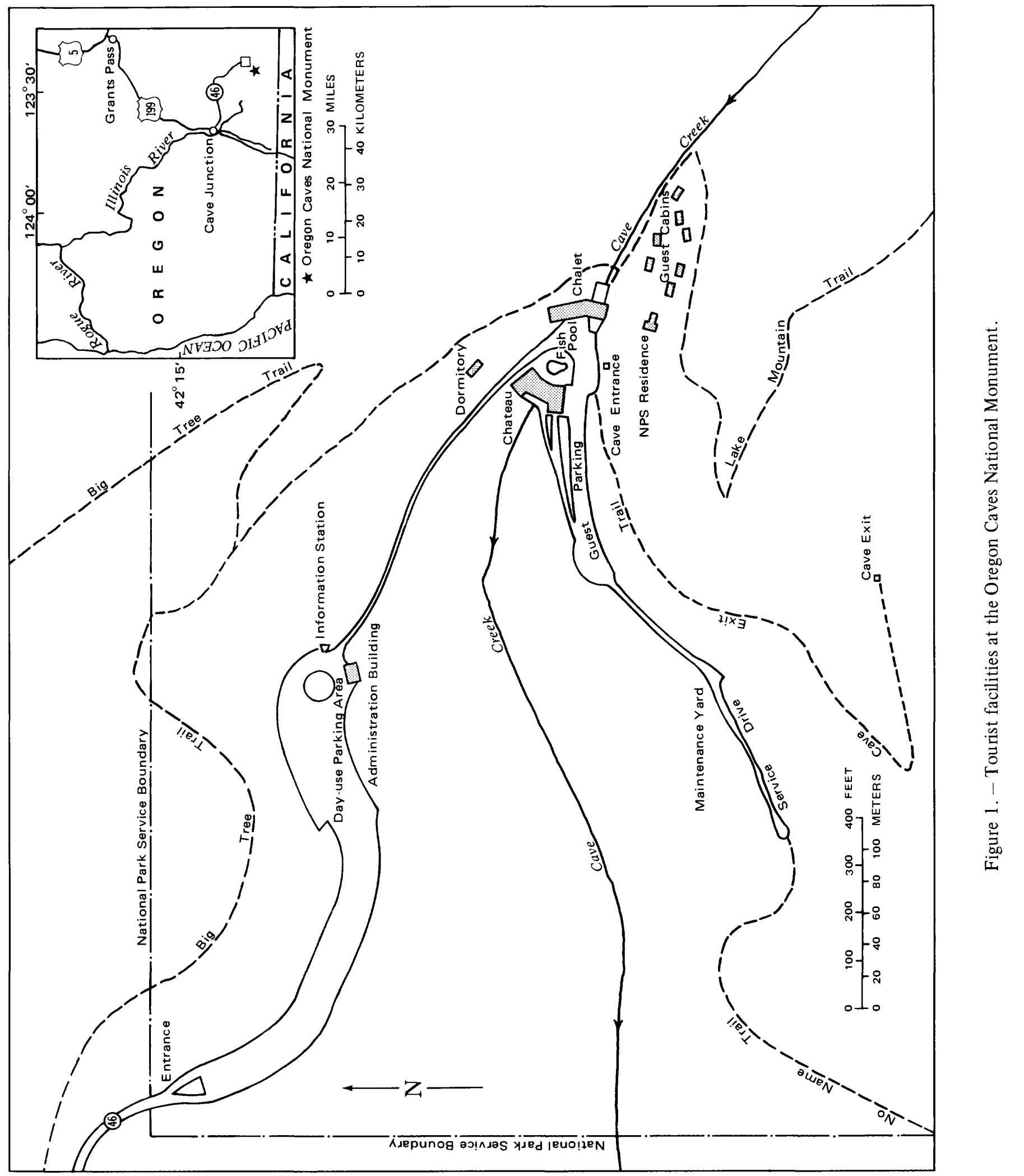


The privately owned tourist facilities consist of a three-story chalet, a six-story chateau, a men's dormitory, and seven hillside guest cabins. A map of the tourist facilities is shown in figure 1. Built in 1923, the chalet occupies the entire width of the Cave Creek waterway. The building contains a gift shop and is used as a women's dormitory during the summer. A covered breezeway connects the gift shop to a restroom and the tour ticket office. The chateau was built in 1934, 160 feet downstream from the chalet. This building also occupies the Cave Creek channel and contains all of the features of a tourist hotel. An 18-inch diameter conduit fed by five catch basins allows low flows to bypass the two structures. The men's dormitory, hillside cabins, and a few National Park Service buildings are located well away from the Cave Creek waterway. Flooding has never been observed within the cave.

\section{DEBRIS FLOW HISTORY}

Flooding has been troublesome in past years, but extensive damage has been avoided by sandbagging the exterior doors of the buildings and diverting water away from the structures. The debris flow on December 22, 1964 could not be diverted. The destructive power of such a flow is also evident at No Name Creek, a small tributary entering Cave Creek 1,800 feet downstream from the chateau. Figure 2 shows the denuded banks 18 years after the debris flow occurred. Trees, up to 40 inches in diameter, once grew at the water's edge.

A series of extreme antecedent weather conditions led to the 1964 debris flows. During the period of December 14 to 17 , western Oregon experienced unusually cold weather with temperatures falling to $21^{\circ} \mathrm{F}$ at Cave Junction. On December 18, a Pacific storm deposited near-record accumulations of snow in the Cascade and siskiyou mountain ranges. By December 20, 40 inches of wet snow had accumulated at the Oregon Caves resort. A warm front then moved inland bringing torrential rains. During the evening of December 21, the temperature was $60^{\circ} \mathrm{F}$ at the chateau; 12 inches of rain fell at Cave Junction in a two-day period ending December 22. On the evening of December 22, the snow at the chateau had melted and water flowed through the breezeway at the chalet.

Harry Christensen, manager of the tourist facilities in 1964, witnessed the debris flow that occurred at 9:00 pm on December 22. The following is an excerpt from a taped interview regarding that event.

When asked where he was when it happened Harry said, "Well you see where that sign says Gift shop (pointing uphill to the left edge of the breezeway)? You see there's a stump there, use to be two stumps. *** We were standing there talking and you could hear this noise just like a freight train was coming down the canyon and I said, "My God, what's that?" All of a sudden, Bob Hines (assistant manager) said, "Run", and we ran. I took off down this ramp, out that way, that log was right behind me." 


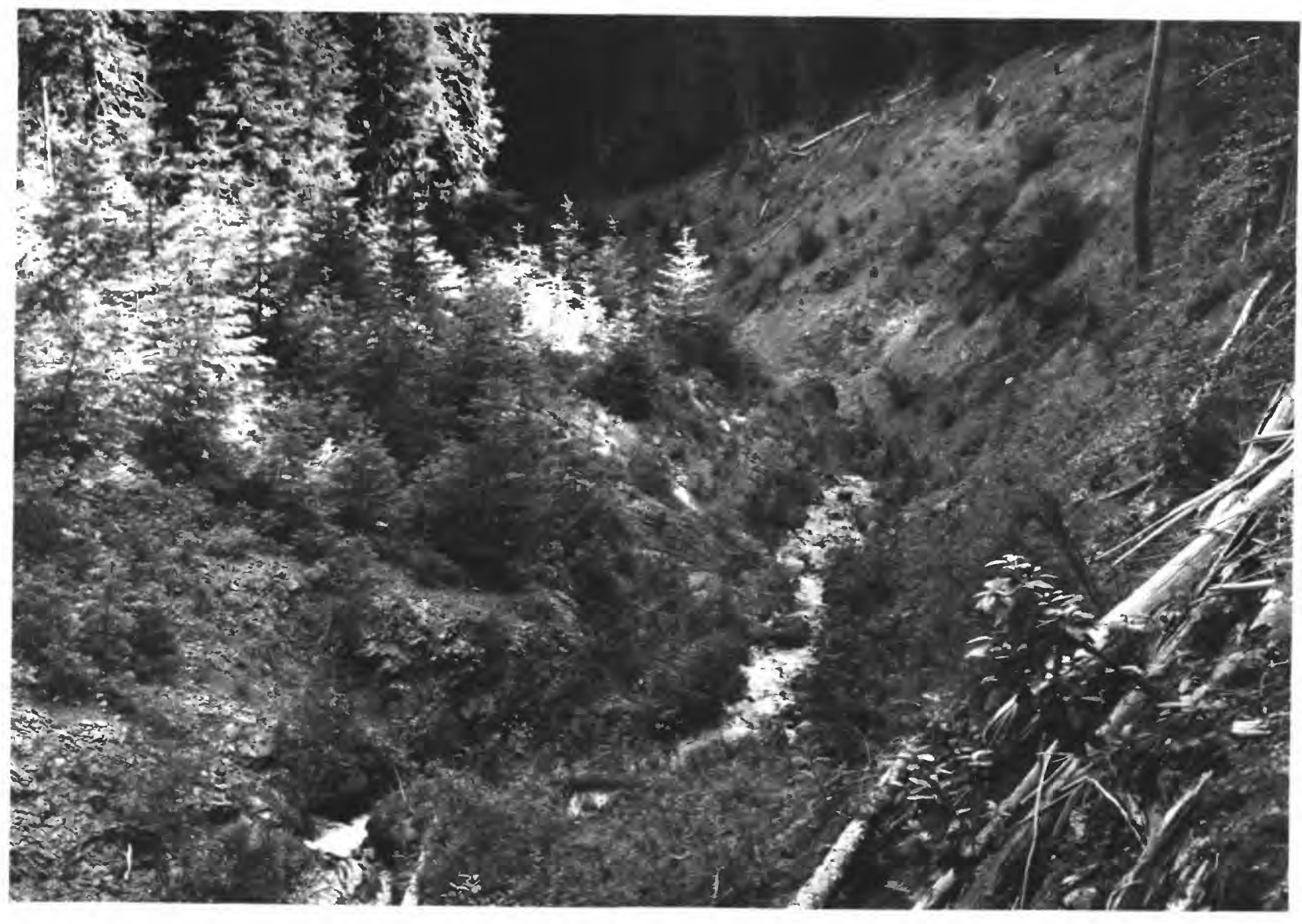

Figure 2. - Debris-flow scar in No Name Creek channel. Streamflow was about 1.5 cubic feet per second when the picture was taken.

The log Harry referred to was riding the crest of the debris wave and was later measured to have a 48-inch diameter. Harry further explained that the passage of the debris flow took no longer than 10-15 seconds. The material was a slurry of gravel and mud with very little water overrun, and the mass came to rest against the upstream wall of the chateau.

Because of his concern that hydrostatic pressure would move the building from its foundation and perhaps topple it into the deep canyon, he opened the doors and windows of the third-floor dining room (upslope ground level) to allow the debris material to flow into and through the building. Sometime later that night, a 20- by 24-inch beam broke and dropped tons of material into the second floor of the chateau. Harry estimated 3,400 $\mathrm{yd}^{3}$ of material was later removed from inside the building. The white arrow in figures 3 and 4 shows the depth of the debris at various locations inside the chateau. 


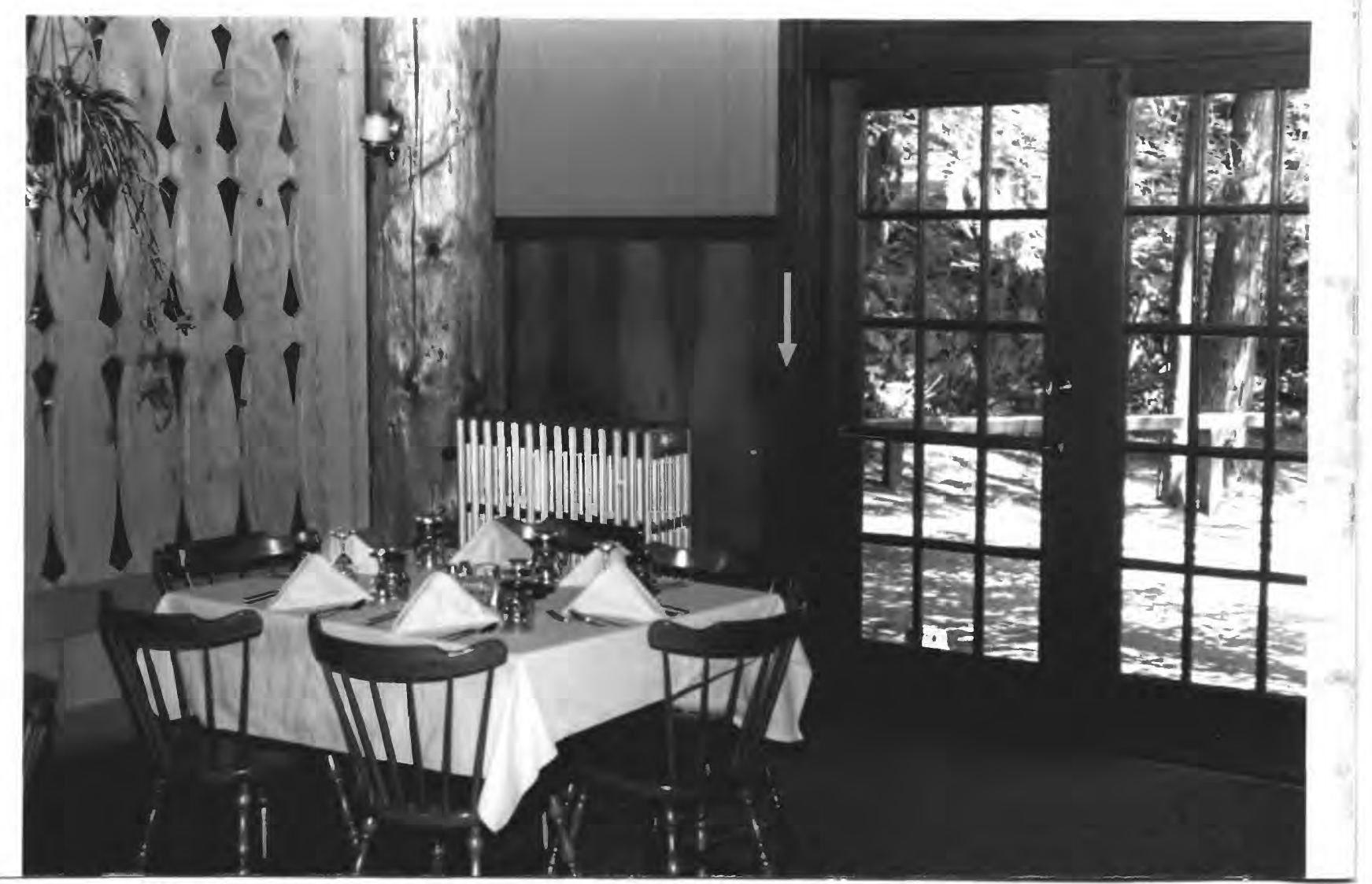

Figure 3. - Mud line in dining-room on third floor. Point of arrow is 54 inches above the floor.

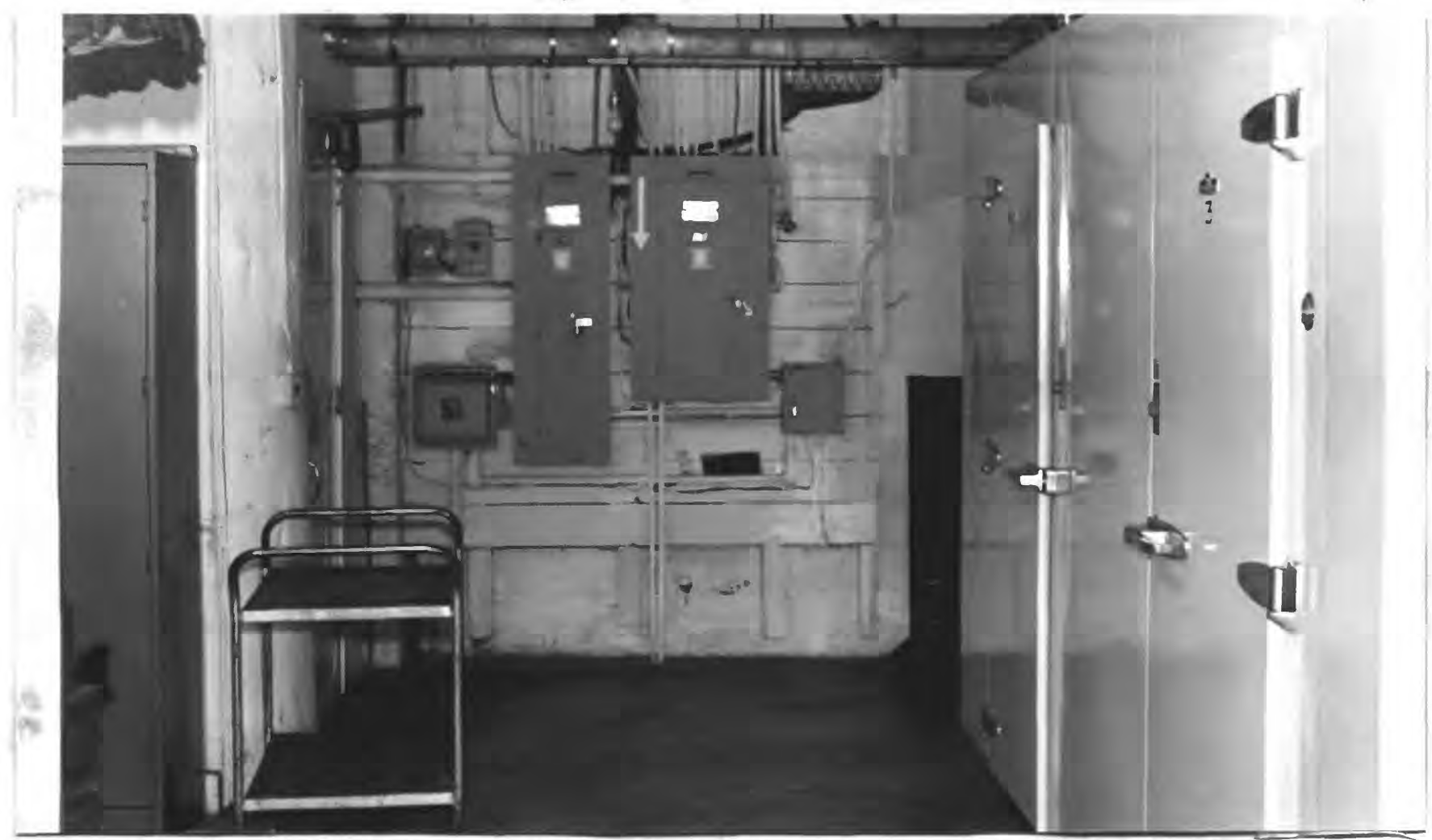

Figure 4. - Mud line in electrical switch box on second floor. Point of arrow is 67 inches above the floor. 
An estimated $1,800 \mathrm{yd}^{3}$ of material was deposited in the area between the chalet and the chateau. The estimate is based on a sketched map of the debris deposit drawn by Warren Johnson (Park Engineer, NPS), photographs of the debris before removal, and the configuration of the terrain surveyed in July 1982. Seventeen trees were extracted from the debris; one was $70 \mathrm{ft}$ long. Figures 5 and 6 show the damage in the breezeway area of the chalet and the deposits of material during cleanup operations. About 5,200 $\mathrm{yd}^{3}$ of material was removed from the area. Damage to NPS facilities, roads, and trails, exceeded $\$ 82,000$; restoration of the privately-owned concession cost $\$ 100,000$.

The source of the debris flow is evidenced by a scar 130 feet downslope from the highest of three crossings of Lake Mountain Trail on the north-facing slope of the drainage. The zone of depletion is about $250 \mathrm{ft}$ long and $6.0 \mathrm{ft}$ deep near the crown (measured normal to the sloping terrain).

Another sidehill scar is evident upslope (north) from the day-use parking lot near the park entrance. Little information is available as to the date of occurrence or the magnitude of this failure. It appears that the movement might have been a slump caused by undercutting the supporting base when the parking lot was widened. This scar can be seen in figure 7 .

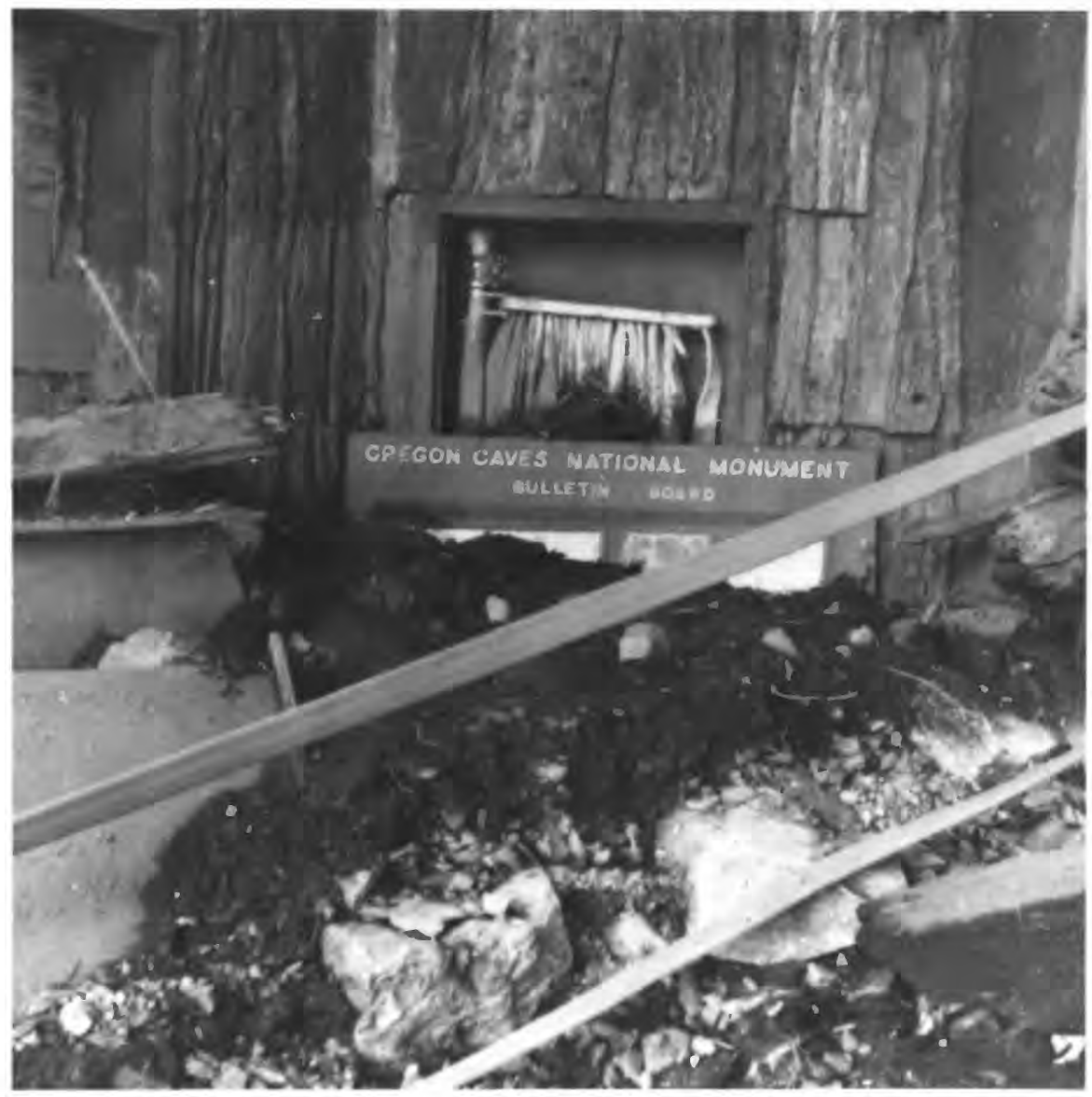

Figure 5. - Debris deposit in breezeway at the chalet. Photo courtesy of the 


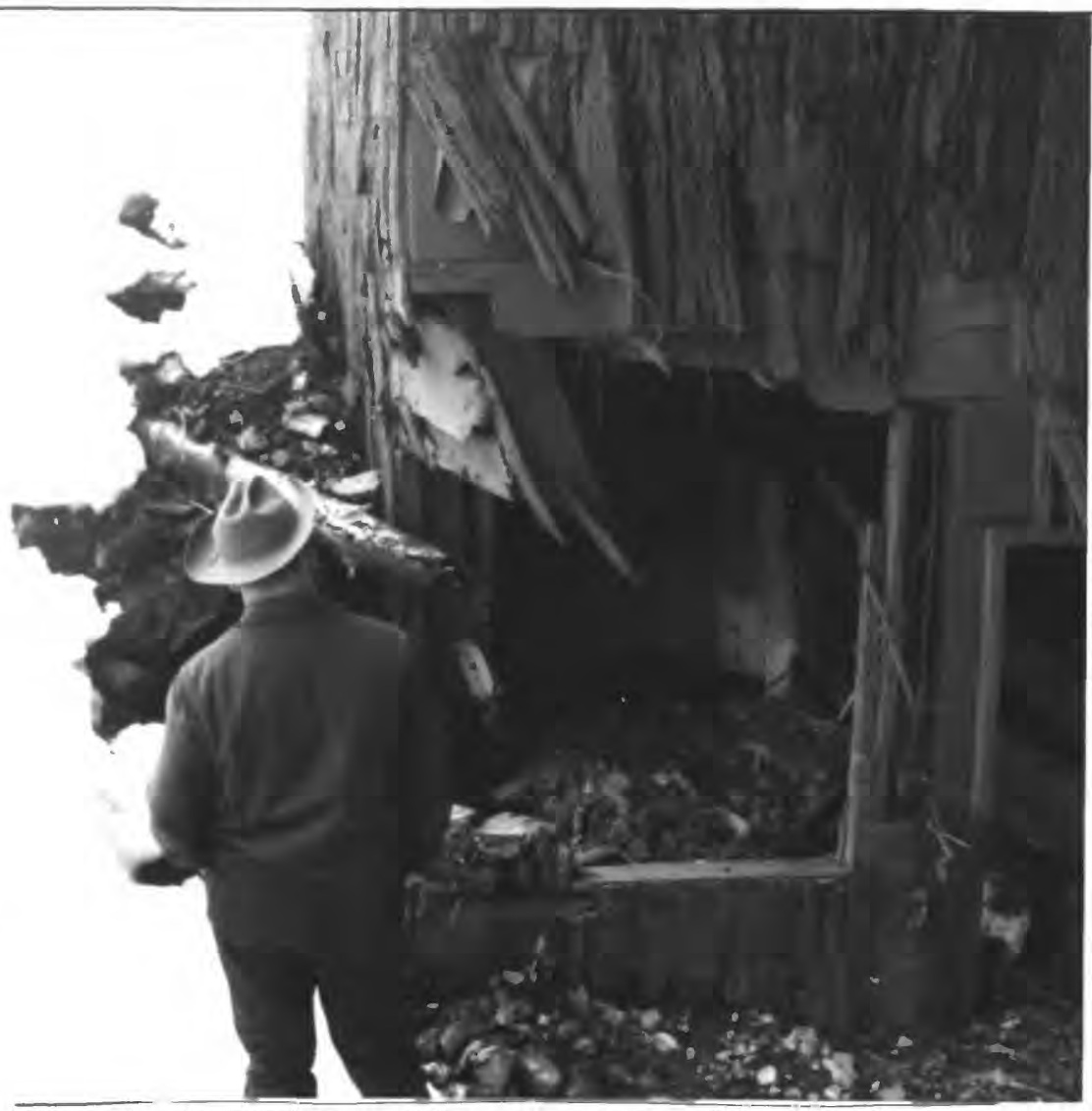

Figure 6. - Debris damage at the upslope corner of the chalet breezeway.

Photo courtesy of the NPS, date unknown.

\section{HYDROLOGY}

Many streams in Oregon reached record peak flows in December 1964. A statistical analysis of peak-flow data collected at a gaging station on Sucker Creek, five miles northwest of the Caves, indicates there is only a 0.5 percent chance that the December 1964 peak could be equalled or exceeded in any given year (U.S. Water Resources Council, 1981).

The peak flow in Cave Creek prior to the arrival of the debris is estimated to be about $75 \mathrm{ft}^{3} / \mathrm{s}$. The estimate is based on observed flow depths in the breezeway and assuming critical flow with a one-third reduction in effective width due to the placement of sandbags at the chalet doors.

An estimated flood-frequency relation for Cave Creek is shown in figure 8. The curve is based on flood equations computed for the coast region in a western Oregon flood-frequency analysis (Harris and others, 1979). Equations presented in that report for the Rogue and Umpqua Rivers region could not be used because the equations do not apply to streams as small as Cave Creek. The curve indicates that the estimated December 1964 peak on Cave Creek would also have a 0.5 percent chance of being equalled or exceeded in any given year. 


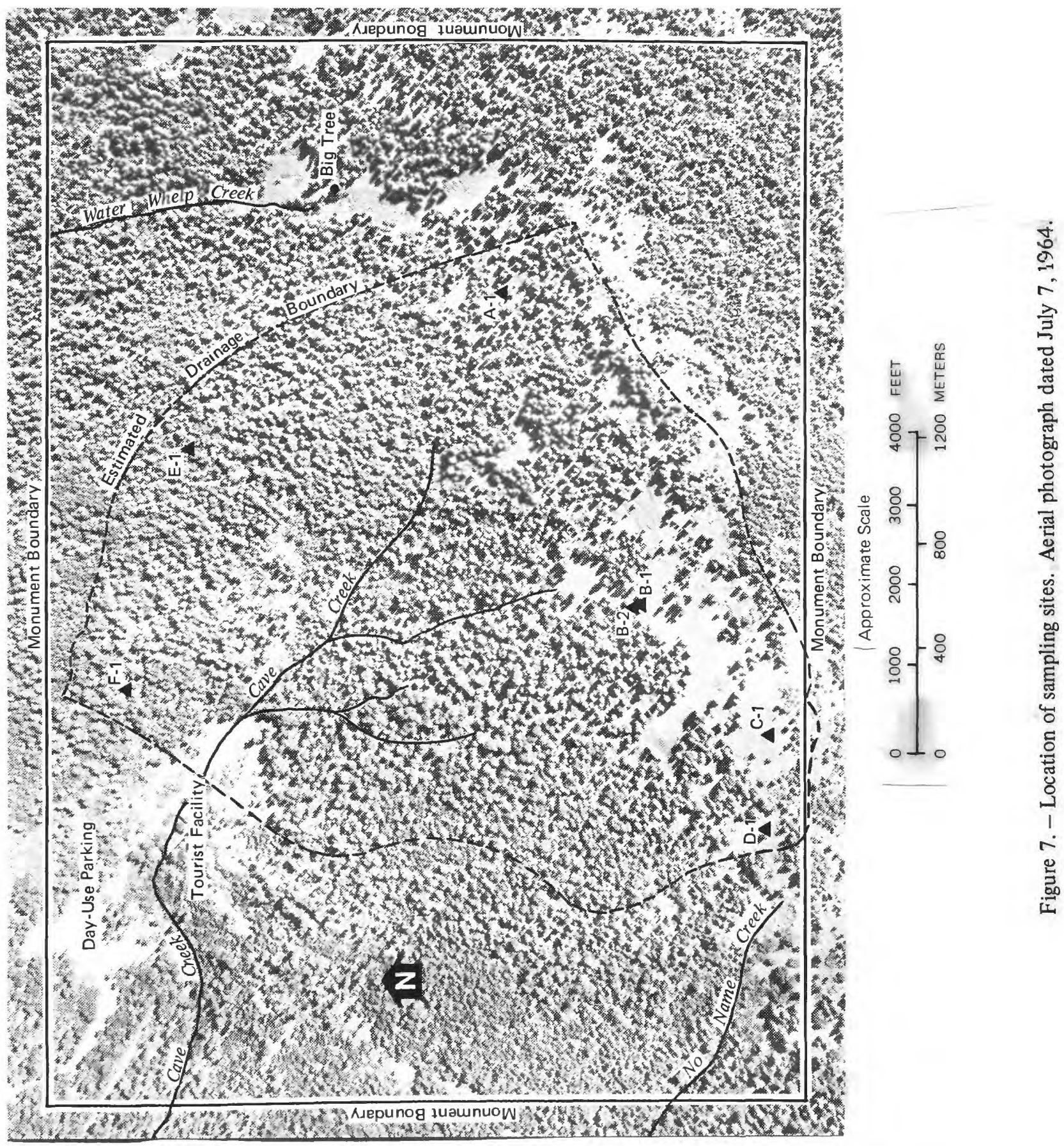




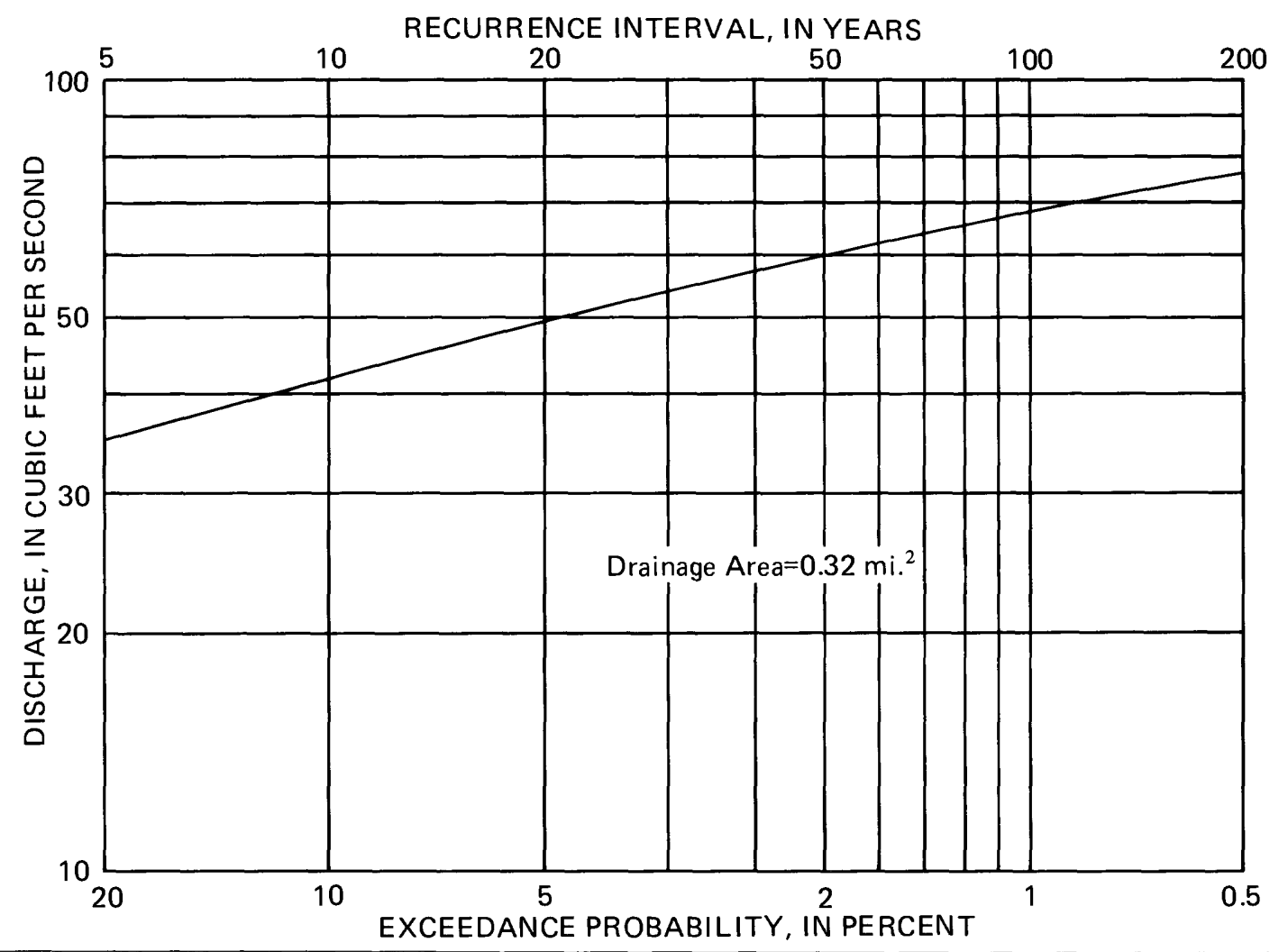

Figure 8. - Estimated flood-frequency curve for Cave Creek at the chalet.

\section{DEBRIS FLOWS}

The 1964 debris flow occurred when the overburden in a small area of the Cave Creek basin reached its liquid limit (Iiquifaction). Liquifaction will occur when the infiltration rate of rainfall and snowmelt exceed the rate of deep percolation below the soil mantle. For this to happen, antecedent rainfall must be adequate to bring the soil moisture up to field capacity (under gravity, water will flow out as readily as it flows $i n)$, and rainfall intensities must continue to be sufficient to maintain the imbalance between infiltration and percolation. 
A quantitative assessment of the amount of moisture needed to initiate a debris flow is difficult because failure depends on soil properties, depth of overburden, slope, and, to some degree, root penetration. However, Campbell (1975), in a comprehensive study of debris flows in the Los Angeles area of southern California, provided some insight into the motivating factors in that area. For example, it generally required 10 inches of antecedent rainfall to bring the soil to field capacity and an intensity of between 0.2 and 0.5 inches per hour (during a 24-hour period) for soils to reach their liquid limit. At Cave Junction, antecedent precipitation during a four-day period ending December 22, 1964, totaled more than 15 inches. The average rainfall intensity on the 22 nd was about 0.34 inch per hour which resulted in an accumulation of 8.12 inches. The 100-year/24-hour rainfall frequency in this area is about 7.8 inches (U.S. National Oceanic and Atmospheric Administration, 1973). Rainfall at the chalet was probably greater than that recorded at the weather station because the chalet is 2,750 feet higher in elevation. The total available moisture should al so include the 40 inches of snow that melted between the 20 th and the 22 nd of December.

Campbell also found that debris flows are most likely to occur in areas having slopes ranging from $26^{\circ}$ to $45^{\circ}$. The soil mantle on steeper slopes generally becomes thinner, exposed bedrock increases, and the occurrence of debris flows becomes unlikely. For the Molalla Creek drainage in the northern Cascade Mountains, the range in slopes susceptible to failure was estimated to be $11^{\circ}$ to $33^{\circ}$ (Brown and others, 1979). In West Virginia, Lessing and others (1976) found that most failures occurred on slopes ranging from $8^{\circ}$ to $19^{\circ}$. Slopes in the Cave Creek drainage generally exceed the lower limiting values of those studies.

A debris flow occurs when earth material becomes fully saturated with water and changes from a plastic to a liquid state. When this happens, a mass movement of material occurs due to the force of gravity and to the lessening of shear strength at the slip plane. No one has reported seeing a debris flow at its inception; however, investigations indicate that the initial movement of the saturated soils causes a reconstitution of the material into a flowing, viscous, debris-laden mass that can attain 'avalanche' velocities (Campbell, 1975). As the debris flow moves downslope, the longitudinal profile displays a buildup of large rock material at its snout. This is due to an upward movement of the larger material caused by the collision of particles and to the faster transportation of material in the upper layer of flow (Takahashi, 1980). The boulder debris is followed, in turn, by an unsorted mixture of rock and gravel, then a slurry of silt-laden water. The finer material sometimes overtakes and overrides the boulders thereby gaining energy as it cascades down the face of the snout (Morton and Campbell, 1978). 
In addition to the work by Campbell in southern California, other debris-flow studies have been made in the Tenmile Range in central Colorado (Costa and Jarrett, 1981), and currently, in the Pollalie Creek drainage of Mount Hood in northwestern Oregon (G. L. Gallino, and T. G. Pierson, U.S. Geological Survey, written commun., 1982). Destructive debris flows have also occurred in Brazil (Vargus and Pichler, 1957), Japan (Oka and Katsurajima, 1971), and coastal Alaska (Bishop and Stevens, 1.964; Swantson, 1969).

\section{SOIL SAMPLING}

Site Properties

To determine the potential hazard from additional debris flow at the Oregon Caves, it was necessary to study the properties of the soil at the source of the 1964 event and compare the material with soils from other locations within the Cave Creek basin. The soils forming the overburden are colluvial, having been derived by the weathering of the parent material and transported by gravitational creep. Known depths range from a few inches at the limestone outcrop near the rim of the basin to more than 132 inches near the chalet (the depth limit of the sampling equipment).

Soil samples were taken at seven sites; one was at the scar of the 1964 debris flow. The other six sites were selected where ground slopes equalled or exceeded the slope at the scar. The location of the sites is shown in figure 7. Some locations are estimated because of orientation problems in the heavily forested areas. The samples were obtained by augering down into the overburden until a firm resistance was met at about the same depth in two or more holes (presumably at the bedrock interface). Samples were taken at various depths wherever there appeared to be a change in color or texture. A description of each site is as follows;

Site A-1

Site $A-1$ is located on the west-facing slope of the basin at the lower of two slippage scars on Lake Mountain Trail, and on a azimuth of $290^{\circ}$ to the day-use parking area. An aluminum identification tag stamped "A-1" is attached to a 24-inch diameter fir tree at the downslope edge of the trail. The small clearing is surrounded by scattered conifer growth; there is no understory, and ground cover consists of broad-leaf plants and grass. The ground slope is $30^{\circ}$; the slope at the face of the scar is $70^{\circ}$.

Three samples were extracted from the exposed minor scarp and are believed to represent material transported from the upper scar to a depth of 92 inches. The curved trunk of a nearby tree may be an indication of soil creep during a long period of time. There is no channel downslope from the scar. A PVC pipe casing was not installed at this site. 
Site B-1

Site B-1 is located on the north-facing slope of the basin near the crown of the scar from the 1964 debris flow. Three samples were obtained from a 52-inch-deep hole at a large clearing, 120 feet downslope from the Lake Mountain Trail. An aluminum tag identifying the site is attached to a 24-inch-diameter tree at the trail directly upslope from the site. A one-inch-diameter PVC pipe casing was installed in the augered hole. The ground cover in the open area consists of broad-leaf plants and grasses with very little brush. The soil samples were very moist suggesting spring seepage. The ground slope is $30^{\circ}$.

\section{Site B-2}

Site B-2 is located at the base of the main scarp of the debris scar, 10 feet downslope from site B-1. The slope of the channel is about $30^{\circ}$; the remaining sidehill bench where most of the failure occurred has a slope of $40^{\circ}$, the face of the scarp, $70^{\circ}$. Dense, shoulder-high ferns prohibited accurate measurements of slope angles. The slip plane was not at the bedrock interface; thus, some material is still available for mass wasting. One sample collected at a depth of 12 inches is believed representative of the soil material exposed after failure occurred. A PVC casing was not installed at this site.

\section{Site C-1}

Site $\mathrm{C}-1$ is also located on the north-facing slope of the basin, 760 feet upslope from the Lake Mountain Trail. Two samples were obtained from a 26-inch-deep hole (with PVC casing) located 180 feet downslope from a boundary-marker tree. The tree is a 100-ft high dead Douglas fir with an attached U.S.D.I. boundary sign. An aluminum tag stamped "C-1" is attached to the sign. The ground slope in this open area is $30^{\circ}$ and the ground cover is a dense growth of broad-leaf plants and grass.

\section{Site D-1}

Site D-1 is about 480 feet west of Site $C-1$ and 100 feet east of the No Name Creek basin divide. The 1964 debris flow in No Name Creek originated from an area about 200 feet west of the divide at about the same elevation. Two samples were obtained from a 29-inch deep hole (with PVC casing) located in a clear area, 45 feet east of three cedar trees growing near the center of the clearing. An aluminum tag stamped "D-1" is attached to the most westerly tree. The ground cover is the same as that at site $\mathrm{C}-1$ and the ground slope is also about $30^{\circ}$. 
Site E-1

Site E-1 is located on the south-facing slope of the basin, about 150 feet northwest of a white outcropping of broken granite and limestone. Dense timber prohibited an exact orientation at this site. One sample was obtained at a 17-inch-deep hole (with PVC casing) surrounded by large Douglas firs, rhododendron bushes, and scattered seedling trees. Very little ground cover grows at this site and the ground slope is $35^{\circ}$.

Site F-1

Site F-1 is also located on the south-facing slope on a azimuth of $210^{\circ}$ to the most easterly cabin in the chalet area. Ten samples were obtained from a 132-inch deep hole, now fitted with a PVC casing, located about 600 feet northeast of the chalet. The site is surrounded by tall cedar and fir trees; there is lit+le brush or ground cover growing in the area. A curvature at the base of nearby trees may be an indication of past soil creep. The ground slope is $32^{\circ}$.

Soil Analysis

Laboratory analyses of the samples were made to determine the liquid limit, the plasticity index, and the size distribution of the material. The liquid limit and plasticity index indicate the effect of water on the strength and consistency of the soil material. As rainfall infiltrates the overburden, the water content increases and the soil changes from a semisolid to a plastic state (the soil becomes pliable). If the water content continues to increase, the soil will change from a plastic to a semifluid state (attaining the consistency of softened butter). The moisture content at the time of these changes is called the plastic and liquid limits of the soil (Atterburg limits). The numerical difference between the plastic and liquid limits is a plasticity index which indicates the range in water content in which the soils are considered plastic.

The results of the Atterburg limits tests are shown in table 1. The tests were made by the Corps of Engineers, North Pacific Division Materials Laboratory, at Troutdale, Oregon. The Atterburg limits tests were made on that part of the material passing the No. 40 sieve $(0.017$ in.), and the soils were classified using the American Society for Testing Materials (ASTM) unified soil classifications (American Society for Testing and Materials, 1966). The Atterburg limits tests cannot be considered definitive because of the organic material in the soils and because the plasticity index values for landslide material are generally higher than those for undisturbed samples (Pomeroy, 1982). However, the tests do provide a good comparison of the plasticity of the soils at each site. 


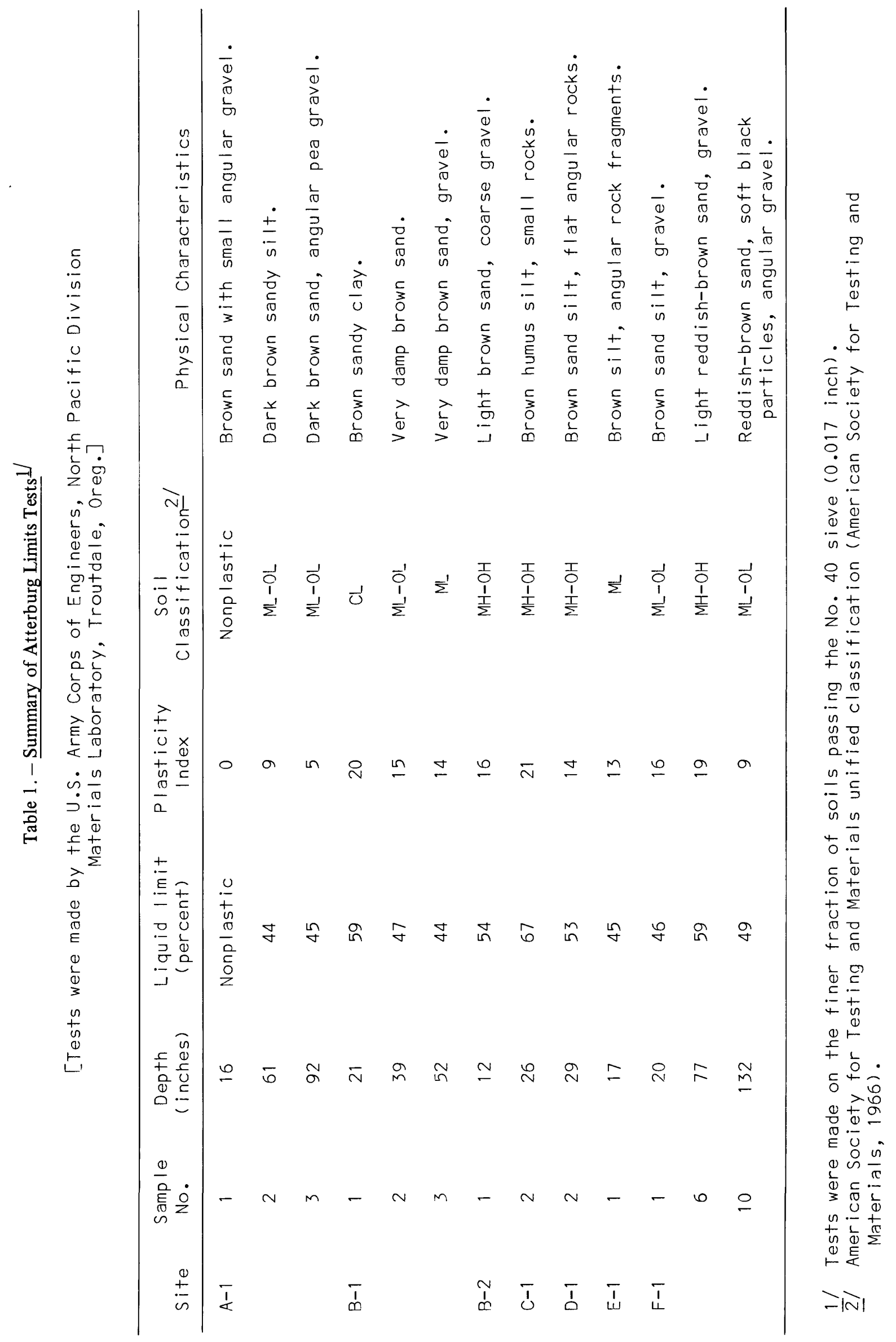


A composite sample of the material collected at each site was analyzed to determine the particle-size distribution in the soils of the overburden. The porosity of a soil determines its water-holding capacities; permeability controls the rate of water infiltration. Coarse, poorly graded material with low clay content generally has a high infiltration rate. Such soils have a frictional resistance to shear due to intergranular locking of the heavier particles. However, the soils strength due to interlocking is quickly lost once the finer material attains liquifaction. The resistance to downslope movement then changes from sliding friction to viscous flow. Soils having a high percentage of fine clay exhibit considerable cohesive resistance to movement. When these soils become saturated, the molecular surface bonding between particles is lessened because the interstitial water weight increases the pore pressure near the slip plane. Soils consisting of fine sand and silt have neither the frictional resistance of gravel nor the cohesive resistance of clay. Such soils are highly susceptible to failure and mass movement. The results of the size analyses are shown in table 2 .

Table 2. - Summary of Particle-Size Analyses

[Analyses by the U.S. Army Corps of Engineers, North Pacific Division Materials Laboratory, Troutdale, Oreg.]

\begin{tabular}{|c|c|c|c|c|c|}
\hline Site & $\begin{array}{r}\text { Compo } \\
\text { tot } \\
\text { Gravel }\end{array}$ & $\begin{array}{l}\text { ition } \\
\text { l we i } \\
\text { Sand }\end{array}$ & $\begin{array}{l}\text { in percent of } \\
+ \text { of sample } \\
\text { Silt and } \mathrm{Clay}\end{array}$ & $\begin{array}{l}\text { Unit dry weight } \\
\text { pounds/cubic feet }\end{array}$ & Classification- \\
\hline$A-1$ & 25 & 44 & 31 & 99 & Silty Gravelly Sand (SM) \\
\hline$B-1$ & 13 & 51 & 36 & -- & Gravelly Silty Sand (SM) \\
\hline$B-2$ & 75 & 24 & 1 & -- & Sandy Gravel (GW) \\
\hline$c-1$ & 16 & 39 & 45 & -- & Gravelly Sandy Silt (ML) \\
\hline $\mathrm{D}-1$ & 14 & 33 & 53 & -- & Gravel Iy Sandy SiIt (ML) \\
\hline$E-1$ & 14 & 39 & 47 & -- & Gravelly Sandy Silt (ML) \\
\hline $\bar{F}-1$ & 83 & 6 & 11 & 88 & $\begin{array}{c}\text { Organic Silty Sandy } \\
\text { Gravel (GP-GM) }\end{array}$ \\
\hline
\end{tabular}

$1 /$ American Society for Testing and Materials unified classification (American Society for Testing and Materials, 1966).

FAILURE POTENTIAL

The failure potential at site $A-1$ arises from the low plasticity of the fine materials rather than from the over-abundance of permeable gravels. The soil is a well-graded silty, gravelly, sand (SM); the fine fraction was 42 percent of the weight of the sample. Whereas the fine material contributes strength to shear-resistance characteristics of the overburden, the liquid limit is among the lowest of the soils tested. The plasticity index shows that a very small increase in water content will cause the soil to reach its liquid limit once it has become plastic. 
The overburden at site B-1 contains very little gravel; the soil is a well-graded gravelly, silty, sand (SM), and the fine fraction accounted for 63 percent of the total weight. The high percentage of silt and an upper mantle of clay indicates the soils at this site are less permeable than at site $A-1$. The properties of the fine material are similar to those at A-1 except these soils will become plastic with less moisture. The radical difference in gravel content between sites B-1 and B-2 may be due to vertical bedding, glaciation, or perhaps to an abrupt change in the composition and weathering of the parent material. Whatever the reason, the lack of gravel is probably why the soil at B-1 didn't fail in 1964.

Having failed in 1964, the soils at site B-2 should be considered potentially hazardous providing there is still enough undisturbed material available for transport. Shoulder-high fern growth limited an accurate appraisal of available material. The soil is a well-graded, sandy gravel (GW); only three percent of the weight of the sample was fine material although some leaching might have occurred shortly after failure. The high plasticity of the fine fraction is probably due to the clay content and to organic material. The depth of the overburden was about 50 inches prior to failure; the slip plane was not at the bedrock interface.

The soils forming the overburden at sites $C-1$ and $D-1$ are a well-graded gravelly, sandy, silt (ML) with a low gravel content. These soils have a low resistance to shear and could become very unstable when saturated. Their proximity to the failure scar on No Name Creek further suggests instability. The sites are near the summit of the basin where there is less material available for transport. Site $\mathrm{C}-1$ has the highest liquid and plasticity index of the soils tested, but this may be due to the organic material in the sample.

Soils at site E-1 are also a well-graded gravelly, sandy, silt (ML) but they are less plastic because the material is inorganic silt and clay. Site $E-1$ is considered susceptible to failure because inorganic soils with low plasticity are highly influenced by gravitational forces (Hough, 1957).

Site $\mathrm{F}-1$ is believed to have the same failure potential as site B-2 except the instability may be lessened somewhat by tree growth in the surrounding area. The soil is a poorly graded organic, silty, sandy, gravel (GP-GM); the fine fraction accounted for only 13 percent of the total weight of the sample. The liquid limit and plasticity index for the fine material is similar to that at site B-2 at a depth of 77 inches. The fine material in the upper and lower horizons has a lower plasticity index which probably indicates less clay and greater permeability. The 132-inch depth of the overburden was the limit of the sampling equipment and not necessarily the bedrock interface. 


\section{HAZARD ABATEMENT}

Because of the energy generated in a debris flow, few protective measures have been effective in arresting or deflecting the flowing material. Reinforcing upslope walls of structures would do little to alleviate the threat of lateral displacement from foundations. Because relocation of the chalet and the chateau is not feasible, hazard abatement must be necessarily limited to preventing injuries and loss of life.

One approach would involve establishing a climatological weather station on the premises from which hourly determinations of rainfall, temperatures, and snow melt (water content) could be made when hazardous conditions are believed imminent. The threshold for such conditions could be estimated from the antecedent daily weather records collected at Cave Junction prior to the 1964 event. When such conditions dictate, vehicular and pedestrian traffic at the tourist facility could be temporarily halted until the hazard alert is terminated.

Another approach would involve installing piezometers in the PVC pipe casings. A piezometer is a pressure-measuring device often used to measure water pressure (piezometric heads) in soils. The piezometer probe should be positioned at the depth of an anticipated failure plane as discussed by Freeze and Cherry (1979, p. 467-470), and by Campbell $(1975, \mathrm{p} .19-20)$. A remote-sensing feature at the installations might also be a consideration. The close proximity of Site F-1 to the facilities might provide a cost-effective power source for such instrumentation. A piezometer installation is believed preferable to an early warning system that is activated after failure occurs because it would al low more time to respond.

A long-term remedy for lessening the potential hazard might be to plant a deep-rooting ground cover in the unstable areas. It is beyond the scope of this report to suggest such types of vegetation.

\section{CONCLUSIONS}

All soils tested in this study are considered to have a failure potential, given the same antecedent weather conditions that occurred pri?ror to the December 1964 event. Sites having high permeability will probably fail first. Even though 24-hour rainfall intensities and the peak surface-water runoff preceding the debris flow are estimated to have recurrence intervals well in excess of 100 years, there is no guarantee that equally severe weather could not occur next year. Although this study has identified sites B-2 and $\mathrm{F}-1$ as problem areas, many more may exist. In view of past soil failures in and around the study area, limiting access to the tourist facilities may be an important consideration when antecedent weather conditions approach those levels of 1964. 


\section{SELECTIED REFERENCES}

American Society for Testing and Materials, 1966, "Grain-size analysis of soils," D422-63, Book of ASTM Standards, Part II, p. 193-201.

Bishop, D. M., and Stevens, M. E., 1964, Landslides on logged areas in southeast Alaska: U.S. Forest Service Research Paper NOR-1 1964, $18 \mathrm{p}$.

Black, C. A., 1965, Methods of Soil Analysis; Part 1, Physical and mineralogical properties, including statistics of measurement and sampling: Madison, Wisc., American Society of Agronomy, no. 9, p. $391-399$.

Brown, W. M., III, Hines, W. G., Rickert, D. A., and Beach, G. L., 1979, A synoptic approach for analyzing erosion as a guide to land-use planning: U.S. Geological Survey Circular 715-L, 45 p.

Campbell, R. H., 1975, Soil slips, debris flows, and rainstorms in the Santa Monica Mountains and vicinity, southern California: U.S. Geological Survey Professional Paper 851, 51 p.

Costa, J.E., and Jarrett, R. D., 1981, Debris flows in small mountain stream channels of Colorado and their hydrologic implications: Bulletin of the Association of Engineering Geologists, v. 18, no. 3, p. 309-322.

Freeze, R. A., and Cherry, J. A., 1979, Groundwater: New Jersey, Prentice-Hall Inc., p. 18-25, 464-472.

Harris, D. D., Hubbard, L. L., and Hubbard, L. E., 1979, Magnitude and frequency of floods in western Oregon: U.S. Geological Survey Open-File Report 79-553, $35 \mathrm{p}$.

Hillel, D., 1971, Soil and water: New York, Academic Press, p. 131-151.

Hough, B. K., 1957, Basic soils engineering: New York, Ronald Press Co., $513 \mathrm{p}$.

Lessing, P., Kulander, B. R., Wilson, B. D., Dean, S. L., and Woodring, S. M., 1976, West Virginia landslides and slideprone areas: West Virginia Geological Survey Environmental Geololgy bull. 15, 64 p.

Morton, D. M., and Campbell, R. H., 1978, Cyclic landsliding at Wrightwood, southern California - A preliminary report: U.S. Geological Survey Open-File Report 78-1079, 23 p. 
Oka, S., and Katsurajima, S., 1971, Topographic investigations for debris flows occurred by the heavy rain in Ashiwada-mura District: Japan Geological Survey bull., v. 22, no. 4, p. 19(179)-60(220).

Pomeroy, J. S., 1982, Landslides in the greater Pittsburgh region, Pennsylvania: U.S. Geological Survey Professional Paper 1229, p. 21 .

State of Oregon, 1979, Geology and mineral resources of Josephine County, Oregon: Department of Geology and Mineral Industries, 45 p.

Swanston, D. N., 1969, Mass wasting in coastal Alaska: U.S. Dept. Agriculture Forest Service Research Paper PNW-83, 15 p.

Takahashi, T., 1978, Mechanical characteristics of debris flow: American Society of Civil Engineers, Journal of the Hydraulics Division, v. 104, no. HY8, Proceedings Paper 13971, p. 1153-1169.

1980, Debris flow on prismatic open channel: American Society of Civil Engineers, Journal of the Hydraulics Division, v. 106, no. HY3, Proceedings Paper 15245, p. 381-396.

U.S. Environmental Protection Agency, 1977, Procedures manual for ground-water monitoring at solid-waste disposal facilities-A current report: EPA-530-SW-611, p. 87.

U.S. National Oceanic and Atmospheric Administration, 1973, precipitation - frequency atlas of the western United States, NOAA Atlas 2, v. X-Oregon: Silver Spring, Md., $43 \mathrm{p}$.

U.S. Soil and Conservation Service, 1982, Guide for using soil survey single-phase interpretation sheets: Soil Conservation Service, $26 \mathrm{p}$.

U.S. Water Resources Council, 1981, Guidelines for determining flood-flow frequency: U.S. Water Resources Council Bulletin 17-B, $28 \mathrm{p}$.

U.S. Weather Bureau, 1964, Mean annual precipitation, 1930-57, State of Oregon: Portland, Oreg., U.S. Soil Conservation Service Map M-4161.

Vargas, M., and Pichler, E., 1957, Residual soil and rock slides in Santos (Brazil): International Conference on Soil Mechanics and Foundation Engineering, 4th, London 1957, Proceedings, v. 2, p. 394-398. 